Article

\title{
The Factors Affecting Farmers' Soybean Planting Behavior in Heilongjiang Province, China
}

\author{
Shiwei Liu ${ }^{1,2} \mathbb{1}$, Pingyu Zhang ${ }^{2}$, Ben Marley ${ }^{3}$ and Wenxin Liu ${ }^{2, *}$ \\ 1 School of Geographical Sciences, Southwest University, Chongqing 400715, China \\ 2 Northeast Institute of Geography and Agroecology, Chinese Academy of Sciences, Changchun 130102, China \\ 3 Department of Sociology, Michigan State University, East Lansing, MI 48824-1111, USA \\ * Correspondence: liuwx@iga.ac.cn; Tel.: +86-431-8554-2228
}

Received: 1 August 2019; Accepted: 28 August 2019; Published: 1 September 2019

\begin{abstract}
Under the threat of food insecurity, the Chinese government has created plans and policies to stimulate soybean production. Despite government efforts to stimulate production, based on predictions, planned targets for soybean production are unlikely. Consequently, the predictions raise questions about farmers' intentions to increase soybean cultivating area. In other words, farmers may not be willing to increase soybean. However, few researchers have studied soybean farmers' intention and behavior. With these concerns in mind, this study analyzed the intention and factors that influence farmers' choice of increasing soybean production as well as evaluating the differences in the decision making between commercial and subsistence farmers. This study collected data from 155 randomly selected families in 23 villages in the major soybean area in Heilongjiang Province. Results showed that $42.6 \%$ of the farmers expressed that they would expand soybean planting area, while the rest would insist on previous planting habits. The capacity to increase soybean production confronted many constraints. Farmers' age, farm income, land topography, and ease of selling all positively influence farmers' behavior. A significant difference in decision making between subsistence and commercial farmers was found. Subsistence farmers were more affected by land topography, agricultural insurance status, and satisfaction of soybean subsidies, whereas commercial farmers were more affected by farming experience and farm income. As a result, soybean policies should focus on increasing farmers' income, promoting large-scale planting, training young farmers, innovation of agricultural insurance, and strengthening construction of agricultural infrastructure.
\end{abstract}

Keywords: soybean; farmer's behavior; soybean planting; affecting factors; Heilongiiang province

\section{Introduction}

Soybean is a globally important crop, providing oil and protein. From 1980 to 2017, global soybean production increased from 80.9 million metric tons (MT) to 336.82 million MT, and the soybean consumption also reached 337 million MT. The increase in demand of a diet rich in animal protein is the product of an increasing standard of living resulting from long-term rapid economic development. Whether used as direct feed for livestock, poultry, and fish or for direct human consumption, there has been a corresponding increase in the demand of soybean. In short, the production and consumption sides of value chains has necessitated the demand for more soybeans.

While soybean has covered the world over, the world-historical origin of soybean is found in China. The Great Soviet Encyclopedia claims soybean cultivation originated in China about 5000 years ago [1]. In 1936, the Chinese soybean production had reached 11.3 million tons, and the production and export had accounted for $80 \%-90 \%$ of the world soybeans [2]. In the 1960s, China's soybean production began to decline, but by the 1980s soybean production started to recover. However, with the mass production of soybeans in the United States, Brazil, and Argentina, China's soybean proportion of 
the world decreased year by year. In 2017, China only accounted for 3.57\% of the world's soybean production. With one of the largest populations in the world with growing disposable income, China has become the largest consumer market of soybean. In 2017, China's soybean consumption accounted for $31.5 \%$ of the world. In order to satisfy domestic soybean consumption, since the 1970s China have imported soybean from United States, Brazil, Argentina, and other countries. In 1996, China implemented a quota management system for soybean imports, and the intra-quota tariff rate was only $3 \%$. Since then, soybean imports have increased rapidly, exceeding soybean exports and making China a net importer.

After entry into the WTO in 2001, China formally abolished the soybean quota restriction, and China's soybean market was completely opened. A new round of globalization disadvantaged Chinese farmers, whose low productivity and low yield of non-GM soybean had to compete globally with GM soybean produced in USA, Brazil, and Argentina. As a result, farmers gradually reduced soybean planting and the government imported more and more soybean. From 2002 to 2017, Chinese imports of soybean increased from 21.4 million MT to 97 million MT, accounting for $63.9 \%$ of world soybean imports (Figure 1). However, soybean production decreased from 16.5 million MT to 14.2 million MT from 2006 to 2017 (Figure 1).

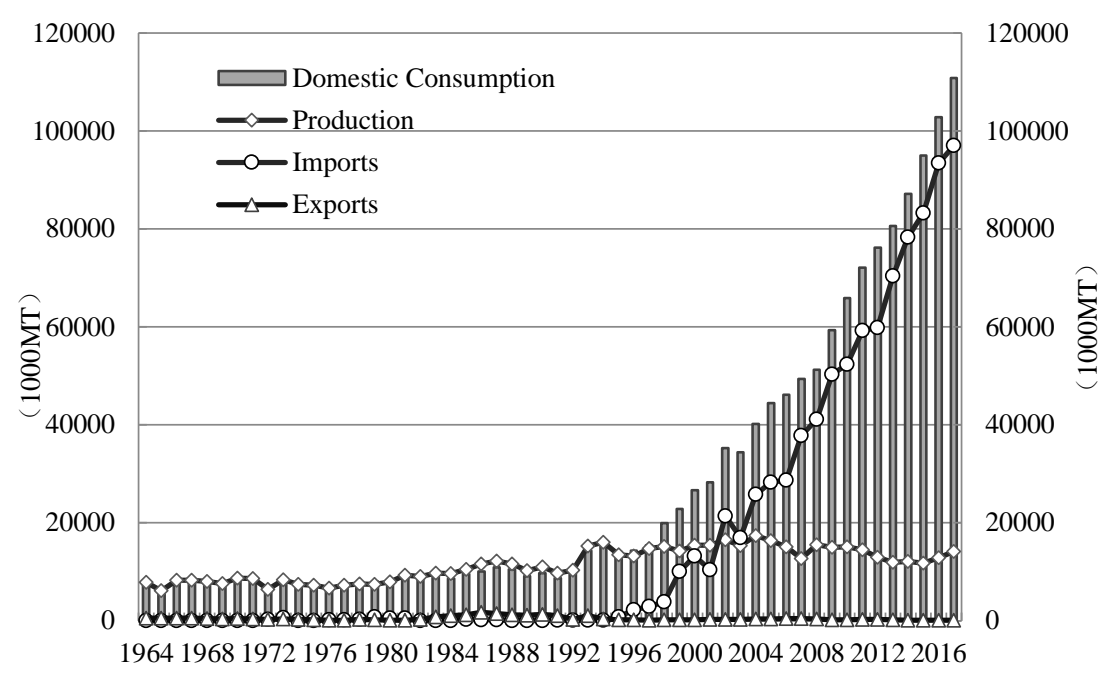

Figure 1. Soybean supply and demand in China. Source: U.S. Department of Agriculture.

In this context, the Chinse government has made efforts to resolve the imbalance in the supply and demand of soybean. In 2008, the Chinese government first introduced temporary reserve policy in soybean production. The temporary reserve price was $3700 \mathrm{CNY} /$ ton in 2008 and increased to $4600 \mathrm{CNY} /$ ton in 2013. However, the policy failed to deliver as soybean production continued to decrease (Figure 1). By 2014, the soybean temporary reserve policy was substituted by target price subsidy, which was mainly implemented in Northeast and Inner Mongolia. The purpose was to reduce the government's interference in agricultural price-making so as to solve the problems of imbalance between supply and demand. Whereas soybean is in relatively short supply, there exists an abundance of corn. The Chinese government initiated a supply-side structural reform in agriculture. In November 2015, China's Ministry of Agriculture and Rural Affairs issued the "Guidance of corn structural adjustment in "Liandaowan' area". The goal was to reduce more than 3.33 million hectares of corn harvest area in the unsuitable planting regions. Farmers of vacated farmland were encouraged to rotate between corn, soybean, and planting other crops. The Ministry of Agriculture and Rural Affairs initiated soybean producer subsidy and corn and soybean rotation subsidy in 2016. In 2016, the Chinese government canceled corn temporary reserve policy and let corn prices depended on the market. Corn price decreased from 2.25 CNY/kg to $1.42 \mathrm{CNY} / \mathrm{kg}$ from 2014 to 2016 in Northeast China. Corn producers can receive a producer subsidy for their loss. In 2017, the government canceled 
soybeans target price subsidy and began to implement a producer subsidy policy. Corn and soybean producer subsidies are unequal. According to the Heilongjiang province government, in 2017, a farmer growing soybean could receive a soybean producer subsidy of $173.46 \mathrm{CNY} /$ acre and in 2018 this subsidy had increased to $320 \mathrm{CNY} /$ acre. At the same time, the corn producers' subsidy in China decreased. In 2016, the corn producer subsidy was $153.92 \mathrm{CNY} /$ acre, while this subsidy hs decreased to $25 \mathrm{CNY}$ /acre in 2018. The producer subsidy of soybean is $295 \mathrm{CNY} /$ acre higher than corn. In addition, soybean and corn rotation farmers can receive a rotation subsidy for 150CNY/acre. Thus, it appears the producer subsidy policy can effectively stimulate farmers to grow more soybeans.

Despite these governmental policies, farmers are the main land managers, and their production decisions crucially affect crop outputs. Understanding the motivations and factors underlying farmers' decision making is fundamental to implementation of government policies. With these concerns in mind, it is important to study the factors influencing farmers' soybean planting behavior. Nevertheless, existing studies in Chinese have mainly studied rice, corn, grain, and other crops, while few studies have explored soybean farmers' decision determinants. Thus, to fill the gap, this paper studied the factors that impact the farmers' soybean planting behavior.

A number of studies have determined that many factors affect farmers' crop planting behavior. Navarrete and Le Bail [3] found that agronomic characteristics such as soil and climate directly affected both the crops and the varieties farmers planted. In Laos, glutinous rice (staple food) tends to be planted on good soils, while cash crops and non-glutinous rice were cultivated on poor soils [4]. In South America, farmers are more likely to plant vegetables and fruits in warmer areas and potatoes and wheat in cooler regions [5]. Additional factors including crop characteristics, such as yields, resistance to pests/drought, cycle period, and maturity dates, are seen as factors influencing a farmer's decision to plant a particular crop [6]. In Haiti, Jaffe [7] observed that some crops have special diseases, pests, or fertility requirements that make the production of the crop difficult or too risky for farmers. Thus, farmers are inclined to choose insect-resistant and disaster-resistant crops to be grown. In Ethiopia, Asrat et al. [8] reported that yield stability is an important attribute for farmers' choice of crop. Beyond agronomic characteristics, some studies deemed economic factors as fundamental. Generally, farmers are willing to grow crops that have a predictable market price and are easy to sell [7]. In Tanzania, Katundu et al. [9] concluded that lower input costs mean that groundnut became the third most important crop.

Numerous studies suggest farmers' personal factors could determine farmers' planting behavior. In Bangladesh, Rahman [10] found that farmers' education, farming experience, farm asset ownership, and non-agricultural income all positively influenced crop diversification. In Kansas, Caldas et al. [11] stated that farmer's perceptions play an important role in the willingness to plant biofuel crops. Beyond the personal level, some scholars regarded the government policy as factors influencing crop selection. Popescu et al. [12] found that land policy applied in the CEEs had a deep impact on the farm crop choices. Yu et al. [13] pointed out after the 2014 Farm Bill, peasants expanded insured crops cultivation. In China, Wu and Cai [14] discovered that a $1 \%$ increase in the grain subsidy caused a $0.096 \%$ increase in grain crop acreage. Besides the above factors, the availability of resources, type of farming, land titling, and location also had significant effects on crop choice [6,15-17]. In general, farmers' crop decisions are complex as they are affected by individual characteristics and external drivers. In this paper, we study the factors affecting farmers' soybean planting behavior from household socioeconomic attributes, farm attributes, and institutional attributes.

The remainder of this paper is structured as follows: The study area and methodology used is defined in the following section (Section 2). Section 3 presents the results, while Section 4 concludes with policy implications. 


\section{Materials and Methods}

\subsection{Study Area}

The study area was conducted in the Heilongjiang province of China located in the mid-western part of Heilongjiang and includes 5 counties: Hailun, Kedong, Beian, Wudalianci, and Nenjiang. This area is the main soybean producing area of Heilongjiang province; $98.3 \%$ of the cultivated land is dry land. The main crops are soybean, corn, and rice, respectively accounting for 51.7\%, 36.3\%, and 5.4\% of the total crop area. This region is located in northeast cold zone. Winters are long and cold, while summers are short with day and night temperatures changing drastically. Importantly, there are less than 90 frost-free days. Crop production in this region is vulnerable to cold, frost, and other disasters. Due to climate change, and in recent years, rising ground temperatures and high profits, the boundary of corn planting in Northeast China has gradually moved north 2 degrees with these areas starting to plant more corn [18]. As Figure 2 shows, percentage of the soybean planting area decreased from $70 \%$ to 52\% in 2004-2015. More recently, with the effects of agricultural policy, the soybean planting area has started to recover. In 2017, percentage of the soybean planting area reached 71.3\%. However, owing to the continuous cropping of corn, soil consolidation and too much herbicide residue affect the increase of crop yield and quality. Moreover, corn grown in this area is mainly de Meyer, with a harder texture that is unpopular with feed processing enterprises. In view of the oversupply of corn in China, China's Ministry of Agriculture issued the "guidance of corn structural adjustment in "Liandaowan' area" (northeast cold zone is one part of "Liandaowan" area), with the main objective to guide markets and shape policy so as to cut corn production and promote corn and soybeans rotation, develop spring wheat, corn silage, expand forage grass, and rape planting in this region.

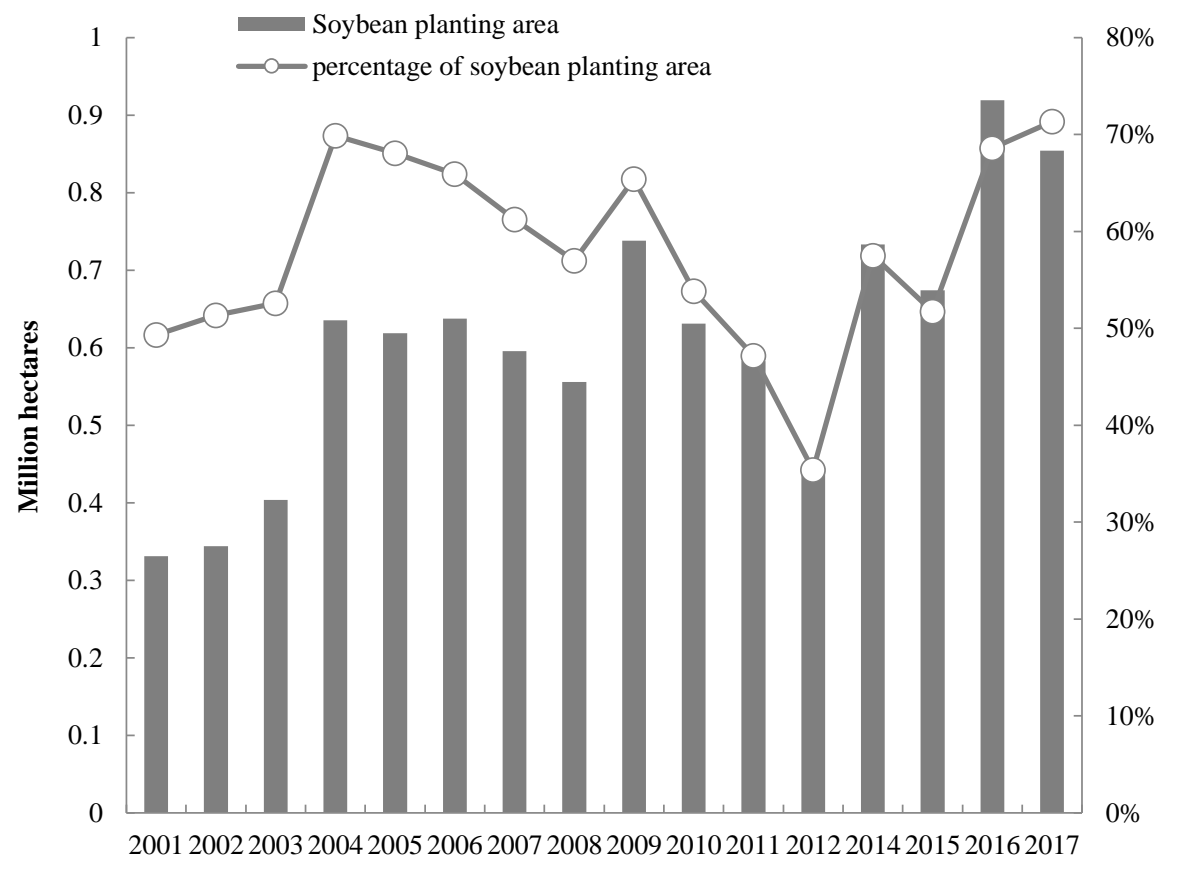

Figure 2. Soybean production in the study area.

\subsection{Data Collection}

We conducted fieldwork in Heilongjiang province in May 2018. A total of 5 counties (Hailun, Kedong, Beian, Wudalianci, and Nenjiang) were visited (Figure 3). A sample of 155 subsistence and commercial farmers were randomly selected from 23 villages in the 5 counties. At each village, questionnaires were administered face-to-face to the heads of households. Respondents were asked about their willingness to cultivate soybean, farmers' personal characteristics, farm income, farmland, irrigation and road facilities, crops production, costs and returns, soybean sales mode, ease of selling, 
sold price, contract farming, crop subsidy, crop insurance, willingness to expand the planting area, planting advice, technical assistance, main problems of growing soybean, etc.

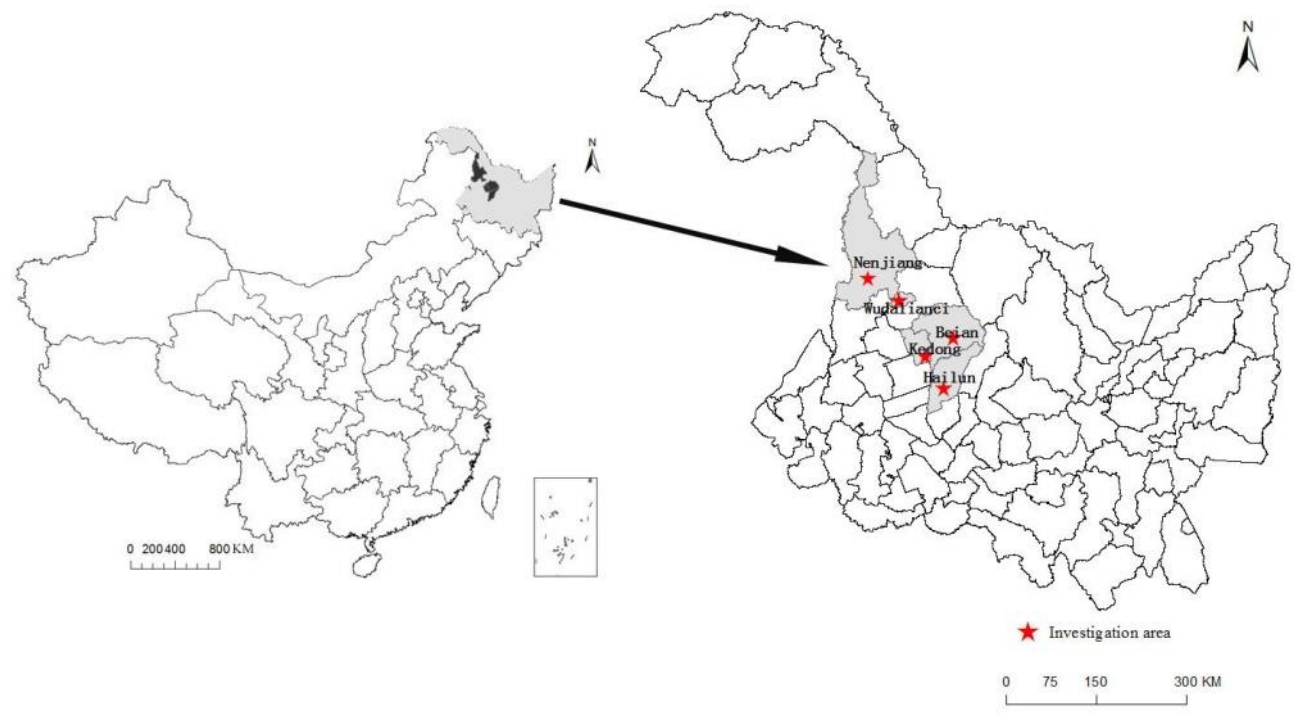

Figure 3. Location of the investigation area.

\subsection{Method}

Logistic regression analysis is a mode usually used when the dependent variable is dichotomous, and one needs to analyze individual decision-making behavior [19]. It has been commonly applied in geographic information analysis [20]. In this study, we asked whether farmers would expand the area planted soybean in 2018. One aim of our survey is to find if the soybean producer subsidy in 2017 effectively stimulated farmers to expand the soybean planting area. Farmers were given four choices: (A) Large-scale expansion of soybean planting area, (B) small-scale expansion of soybean planting area, (C) no expansion, planting soybean as before, or (D) reduce soybean planting area. We attempted to use a cumulative logistic model estimated data in SPSS16.0. However, the result was unsatisfactory, considering that there were only two farmers who chose to reduce the soybean planting area. Despite this, we used the binary logistic mode in this paper. Farmers' decision is represented by a binary $(\mathrm{Y})$ consisting of two codes: $Y=1$, if a farmer plans to expand soybean planting; otherwise, we set $Y=0$. The binary logistic regression model is shown below:

$$
\begin{gathered}
\mathrm{P}\left(Y=1 \mid x_{1}, x_{2}, \cdots, x_{m}\right)=\frac{e^{\left(\beta_{0}+\sum \beta_{i} x_{i}\right)}}{1+e^{\left(\beta_{0}+\sum \beta_{i} x_{i}\right)}} \\
\operatorname{logitP}\left(Y=1 \mid x_{1}, x_{2}, \cdots x_{m}\right)=\ln \left(\frac{P}{1-P}\right)=\beta_{0}+\beta_{1} x_{1}+\cdots+\beta_{m} x_{m}
\end{gathered}
$$

where subscript $i$ denotes the $i$-th observation in the sample, P represents the dependent variable, $\beta_{0}$ is a constant, $\beta_{1}, \beta_{2}, \ldots, \beta_{m}$ are regression coefficients of variables $x_{1}, x_{2}, \ldots, x_{m}$, respectively, which can reveal the possible impact of each independent variable exerted on the dependent variable [21]. In this study, in order to study the difference of soybean planting behavior between subsistence farmers and commercial farmers, we also each established one regression model for subsistence farmers and commercial farmers.

\section{Results and Discussion}

\subsection{Descriptive Statistics}

Table 1 provides a description of the variables used in the regression models. The following descriptive statistics are for the full sample of farmers $(n=155)$. The explanatory variables are either binary (e.g., land acquisition means, agricultural insurance status, membership in cooperative, 
planting advice, technical assistance) or continuous variables (e.g., Household size, farm size, farming experience, and soybean price). As it is shown in Table 1, average age of respondents was 52.5 years old. Further, $61.9 \%$ of the farmers are over 50 years old. This implies that those who make decisions in household farming are mainly middle-aged and elderly people over 50 . Educational levels are low, and $53.8 \%$ of them have only a primary school education. Average farm labor is only 1.8 ; that is, there is only one or two farm workers per household. According to the survey data, $89 \%$ of the households have no young labor force, and farming work is undertaken by the elderly, which is mainly elderly couples. Farming experience in all districts is long with the average years of farming over 28 years. The average land holding size is about 9.1 ha, which is higher than the national average $0.27 \mathrm{ha}$. That is because land transaction is common in this area and about $56.1 \%$ of the family rented land for cultivation. Land fragmentation is serious. Most of family's arable land is scattered and not concentrated together. The average amount of arable land is more than six plots in a household. Agricultural infrastructure construction is unsatisfactory in this region; $93.6 \%$ and $70.5 \%$ of the farmers said irrigation facilities and road facilities are in bad situation.

Table 1. Description of variables used in the binary logistic regression model $(n=155)$.

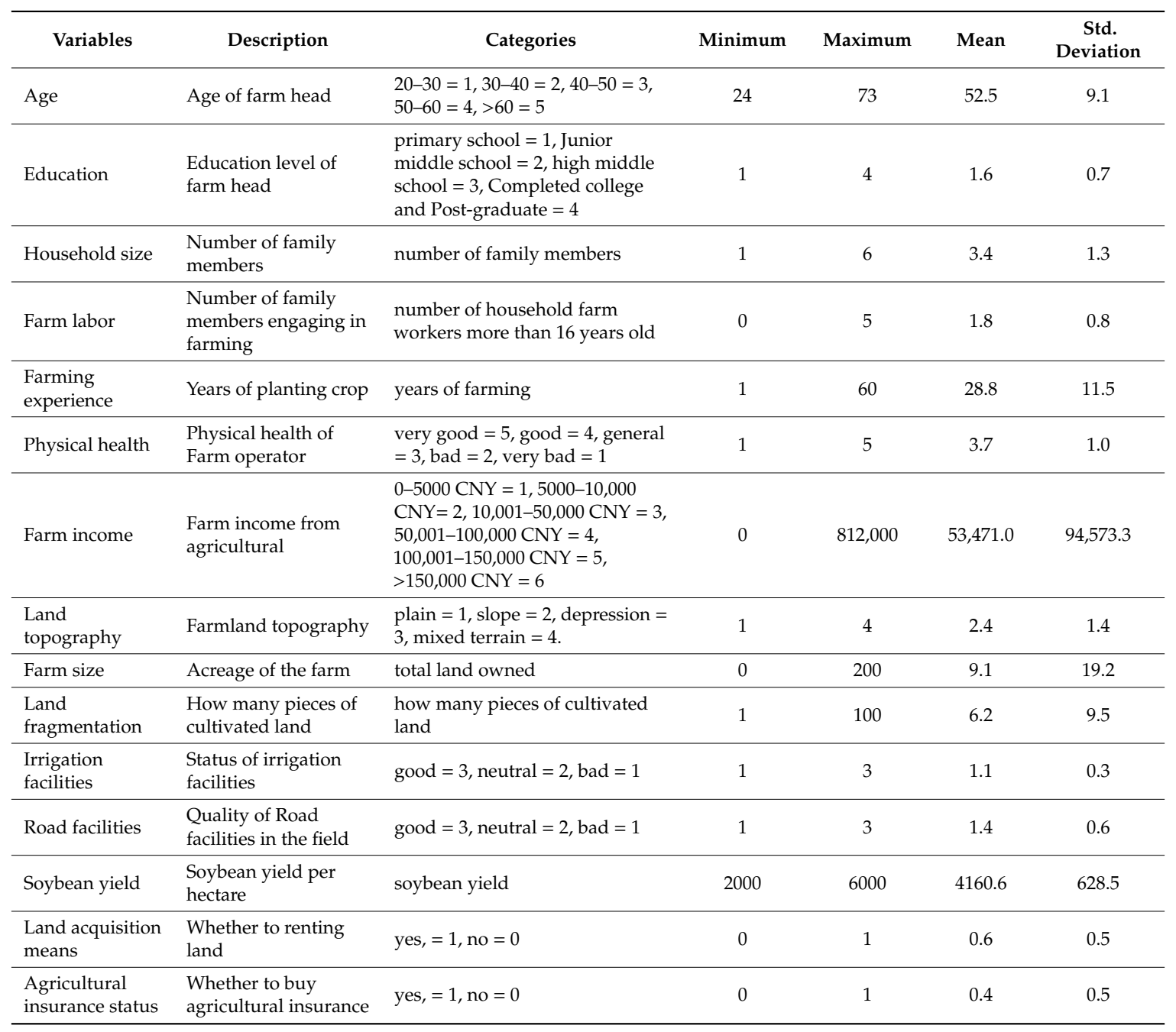


Table 1. Cont.

\begin{tabular}{|c|c|c|c|c|c|c|}
\hline Variables & Description & Categories & Minimum & Maximum & Mean & $\begin{array}{c}\text { Std. } \\
\text { Deviation }\end{array}$ \\
\hline $\begin{array}{l}\text { Soybean sales } \\
\text { mode }\end{array}$ & $\begin{array}{l}\text { Soybean marketing } \\
\text { channels }\end{array}$ & $\begin{array}{l}\text { market sales }=1 \text {, Hawker-to-door } \\
\text { acquisition }=2 \text {, Cooperative } \\
\text { acquisition }=3 \text {, Enterprise } \\
\text { acquisition }=4 \text {, Grain Station } \\
\text { acquisition }=5 \text {, online sales }=6 \text {, } \\
\text { Mixed sales }=7\end{array}$ & 1 & 7 & 2.8 & 1.4 \\
\hline Soybean price & $\begin{array}{l}\text { Soybean sold prices } \\
\text { last year }\end{array}$ & product sold prices last year & 2 & 2 & 1.7 & 0.1 \\
\hline Planting cost & $\begin{array}{l}\text { Farmers' perception } \\
\text { of soybean planting } \\
\text { costs }\end{array}$ & $\begin{array}{l}\text { very high }=1 \text {, high }=2, \text { general }= \\
3, \text { low }=4, \text { very low }=5\end{array}$ & 1 & 5 & 1.9 & 0.6 \\
\hline Soybean subsidy & $\begin{array}{l}\text { Soybean subsidy } \\
\text { amount last year }\end{array}$ & $\begin{array}{l}0-5000 \mathrm{CNY}=1,5000-10,000 \\
\mathrm{CNY}=2,10,000-50,000 \mathrm{CNY}=3, \\
50,000-100,000 \mathrm{CNY}=4, \\
>100,000 \mathrm{CNY}=5\end{array}$ & 520 & 520,000 & $23,722.0$ & $50,076.9$ \\
\hline $\begin{array}{l}\text { Soybean subsidy } \\
\text { payment } \\
\text { principle }\end{array}$ & $\begin{array}{l}\text { Cognition of subsidy } \\
\text { payment principle }\end{array}$ & $\begin{array}{l}\text { very reasonable }=2, \text { neutral }=1 \text {, } \\
\text { unreasonable }=0\end{array}$ & 0 & 2 & 1.4 & 0.7 \\
\hline $\begin{array}{l}\text { Soybean subsidy } \\
\text { payment mode }\end{array}$ & $\begin{array}{l}\text { Cognition of farmers' } \\
\text { subsidy payment } \\
\text { mode }\end{array}$ & $\begin{array}{l}\text { very reasonable }=2, \text { neutral }=1 \text {, } \\
\text { unreasonable }=0\end{array}$ & 0 & 2 & 1.7 & 0.5 \\
\hline $\begin{array}{l}\text { Satisfaction of } \\
\text { soybean } \\
\text { subsidies }\end{array}$ & $\begin{array}{l}\text { Farm head's } \\
\text { satisfaction with } \\
\text { current soybean } \\
\text { subsidies }\end{array}$ & $\begin{array}{l}\text { strongly satisfied }=5, \text { satisfied }= \\
4, \text { neutral }=3, \text { dissatisfied }=2, \\
\text { strongly dissatisfied }=1\end{array}$ & 1 & 5 & 3.1 & 0.9 \\
\hline
\end{tabular}

\subsection{Farmers' Intentions}

The survey result showed that $42.6 \%$ of the farmers said that they would expand their soybean planting area. Farmers seriously considered expanding soybean production because they believed they would receive a subsidy for soybean. Further, $57.4 \%$ of the farmers expressed they would insist on the previous planting habits, because they want aversion risk and the area of cultivated land is limited. Risk aversion ensures the long-term sustainability of farming families. Moreover, the soybean price last year was too low, and the soybean producer subsidy was not enough to offset the loss of the price. Most farmers said they had not received the rotation subsidy, because the subsidy requires that soybean planting area concentrate more than $5.33 \mathrm{ha}$, and the crop last year planted must be corn.

\subsection{Factors Influencing Farmers' Soybean Planting Behavior}

\subsubsection{All Farmers}

The binary logistic regression result of the factors affecting the farmers' soybean planting behavior are presented in Table 2. The logistic model showed model chi-square $=20.58$ and $p=0$, which implies significance at the one percent level. The study log likelihood chi-square statistic is 166.38 . The association between the dependent and explanatory variables is also strong, as described by Nagelkerke $\mathrm{R}^{2}=0.19$, indicating fitness of model predictors for prediction dichotomous dependent variable. 
Table 2. Binary logistic regression estimates of the factors affecting the farmers' soybean planting behavior $(n=155)$.

\begin{tabular}{cccc}
\hline Variables & All Farmers & Commercial Farmer & Subsistence Farmers \\
\hline Age & $0.018^{* *}$ & 0.707 & 0.11 \\
Education & 0.158 & 0.199 & 0.757 \\
Household size & 0.935 & 0.846 & 0.121 \\
Farm labor & 0.546 & 0.781 & 0.823 \\
Farming experience & 0.894 & $0.035^{* *}$ & 0.707 \\
Physical health & 0.23 & 0.877 & 0.505 \\
Farm income & $0.004 * * *$ & $0.006 * *$ & 0.885 \\
Land topography & $0.017^{* *}$ & 0.971 & $0.002^{* * *}$ \\
Farm size & 0.978 & 0.715 & 0.709 \\
Land fragmentation & 0.742 & 0.866 & 0.974 \\
Irrigation facilities & 0.978 & 0.641 & 0.741 \\
Road facilities & 0.157 & 0.379 & 0.147 \\
Soybean yield & 0.806 & 0.793 & 0.972 \\
Land acquisition means & 0.732 & 0.881 & 0.776 \\
Agricultural insurance status & 0.857 & 0.574 & $0.096^{*}$ \\
Soybean sales mode & 0.766 & 0.763 & 0.549 \\
Ease of selling & $0.09 *$ & 0.34 & 0.904 \\
Soybean price & 0.822 & 0.808 & 0.802 \\
Planting cost & 0.236 & 0.795 & 0.208 \\
Membership in cooperative & 0.273 & 0.837 & 0.163 \\
Soybean subsidy & 0.921 & 0.484 & 0.667 \\
Soybean subsidy payment principle & 0.558 & 0.994 & 0.861 \\
Soybean subsidy payment mode & 0.443 & 0.355 & 0.512 \\
Satisfaction of soybean subsidies & 0.45 & 0.889 & $0.068^{*}$ \\
Planting advice & 0.329 & 0.539 & 0.705 \\
Technical assistance & 0.454 & 0.527 & 0.015 \\
Constant & $0.089 *$ & $0.002 * * *$ & \\
\hline
\end{tabular}

Notes: Significance levels ${ }^{* * *} p<0.01,{ }^{* *} p<0.05,{ }^{*} p<0.1$.

As Table 2 shows, the influence of explanatory variables is all positive. The results highlight that for the full farmers, intentions are influenced significantly by age ( $5 \%$ level), farm income ( $1 \%$ level), land topography ( $5 \%$ level), and ease of selling ( $10 \%$ level). It seems that the older farmers have more possibility of expanding soybeans. China is now in the stage of accelerating urbanization, and more and more young farmers are migrating to cities. Householders will consider the shortage of labor force in agricultural production and reduce the cultivation of labor-intensive crops [22]. Elderly farmers have cultivated soybeans for many years, and now that the Chinese government initiated a new soybean subsidy, they are more willing to expand the cultivation area.

According to our analysis, farm income is significant for the farmers' soybean planting behavior. Farmers with more agriculture income are more likely to increase soybeans. The results suggest that farmers' objective is to maximize profits and to plant crops with guaranteed income. As Caldas et al. [11] found, uncertainty of financial returns should decrease farmer's attitude towards new crops, while if the crop is a familiar crop, they are willing to increase the cultivation area.

Land topography is another factor that affects farmer's intention. Farmers are more likely to increase soybean when the terrain is complex. According to Li and Li [22], flat land is easy to tillage, renovate, and is more suitable for planting rice and other water-demanding crops, while the fields on slopes and depressions are generally fragmented, and water resources are insufficient, so it is not suitable for planting water-demanding crops. Soybean can grow in a wide range of soils. When farmers make production decisions, they will intend to make full use of slope and depression land to increase soybean production.

Ease of selling is another factor significantly influencing farmers' soybean planting behavior. If soybean sales are easier, farmers will be more willing to increase soybeans production. The survey 
results showed that $31.6 \%$ of farmers expressed that selling soybean is very easy, $47.7 \%$ expressed easy, and $20.6 \%$ expressed difficult. In China, soybean has six selling modes: market sales, hawker-to-door acquisition, cooperative acquisition, enterprise acquisition, grain station acquisition, and online sales. In the study area, $71 \%$ of the selling depended on hawker-to-door acquisition. That is, after the soybean harvest, many traders will visit their home to purchase so that they do not need to travel a long way to the town. If the farmer lives not far from the government grain station, they will directly transport soybeans to grain depots. So, this selling mode in the study area accounts for $20 \%$. If the farmer cooperates with an enterprise or farmer cooperative, they will directly sell to them. However, the other two market types only account for $3.9 \%$ and $0.6 \%$, respectively. The rest are selling on market or mixed selling. Overall, soybean sales are relatively easy. One farmer in Hailun said that he planted coarse cereals last year. However, there is no hawker-to-door acquisition for coarse cereals and the grain stations also do not purchase. Although the prices of coarse cereals in supermarkets are high, they insisted on planting soybean this year. The results indicated that farmers like to grow crops that are marketable and easy to sell.

\subsubsection{Commercial Farmers}

Commercial farmers are farmers who have enough land to produce agricultural output that exceeds the poverty level defined by the World Bank, and some of them have enough farm income to take on city-oriented consumption patterns [23]. In China, due to regional differences, there is no clear and unified notion for defining the commercial farmer and subsistence farmers in academia and government [24]. So, in this paper, we use Mellor and Malik [23] in Pakistan's experience, and define commercial farms for China as those with more than 75 acres of farmed land, and below 75 acres are subsistence farmers. In all, there were 89 subsistence and 66 commercial farmers questioned. The variable attributes between commercial farmer and subsistence farmer are shown in Table 3 . The results showed that the commercial farmers are younger than the subsistence farmers overall; the average age of commercial farmer is 49.5 and subsistence farmer is 54.8. Education level, household size, farm income, farm size, land fragmentation, soybean yield, and soybean subsidy of commercial farmers are also higher than subsistence farmers, while the farm labor and agriculture experience of commercial farmers is not as high as subsistence farmers. This implies that although the commercial farmer has less farming experience and fewer farm labors, they have higher income and soybean yield. That means production efficiency of commercial farmers is higher than the subsistence farmers in the study area. This result is consistent with Yang et al.'s [25] study that agricultural leading enterprises and family farms have obvious advantages in the field crop production, including agricultural mechanization and productivity efficiency. Another interesting fact is land acquisition means of commercial farmers. Almost $95 \%$ of the commercial farmers have rented land from other farmers. This is consistent with the current policy encouraged by the Chinese government, which promotes rural land concentrate to large commercial farmers and improves the efficiency of agricultural production of the region.

Table 2 shows that commercial farmers' soybean planting behavior are significantly influenced by farming experience ( $5 \%$ level). A similar study by Nahayo et al. [26] also indicated that experienced farmers are more likely to rely on the traditional farming practices than the less experienced ones. After all, new crops mean new risks, and experienced farmers are willing to expand a familiar crop. In this study area, soybean is a familiar crop for commercial farmers and this area is also suitable for planting soybeans. So, experienced commercial farmers are more willing to expand soybean. Expanding soybean production has another benefit for commercial farmers. They can get rotation subsidy if they utilize a corn-soybean rotation. In Heilongiiang province, owing to the limited subsidy funds, not every farmer rotation can get the subsidy, only those households that concentrate more than 5.3 hectares receive the rotation subsidy. Farming households with land fragmentation, a common phenomenon in the region, usually do not qualify for rotation subsidies. Thus, primarily commercial farmers are the main beneficiaries of the rotation subsidies. However, subsidy is not a significant influencing factors for commercial farmers in our study because most of the commercial farmers 
reported that land rent and subsidy rise simultaneously. 'So the subsidies criteria increase doesn't make much sense to us' one commercial farmer said.

Table 3. Description of variables between commercial farmer and subsistence farmer $(n=155)$.

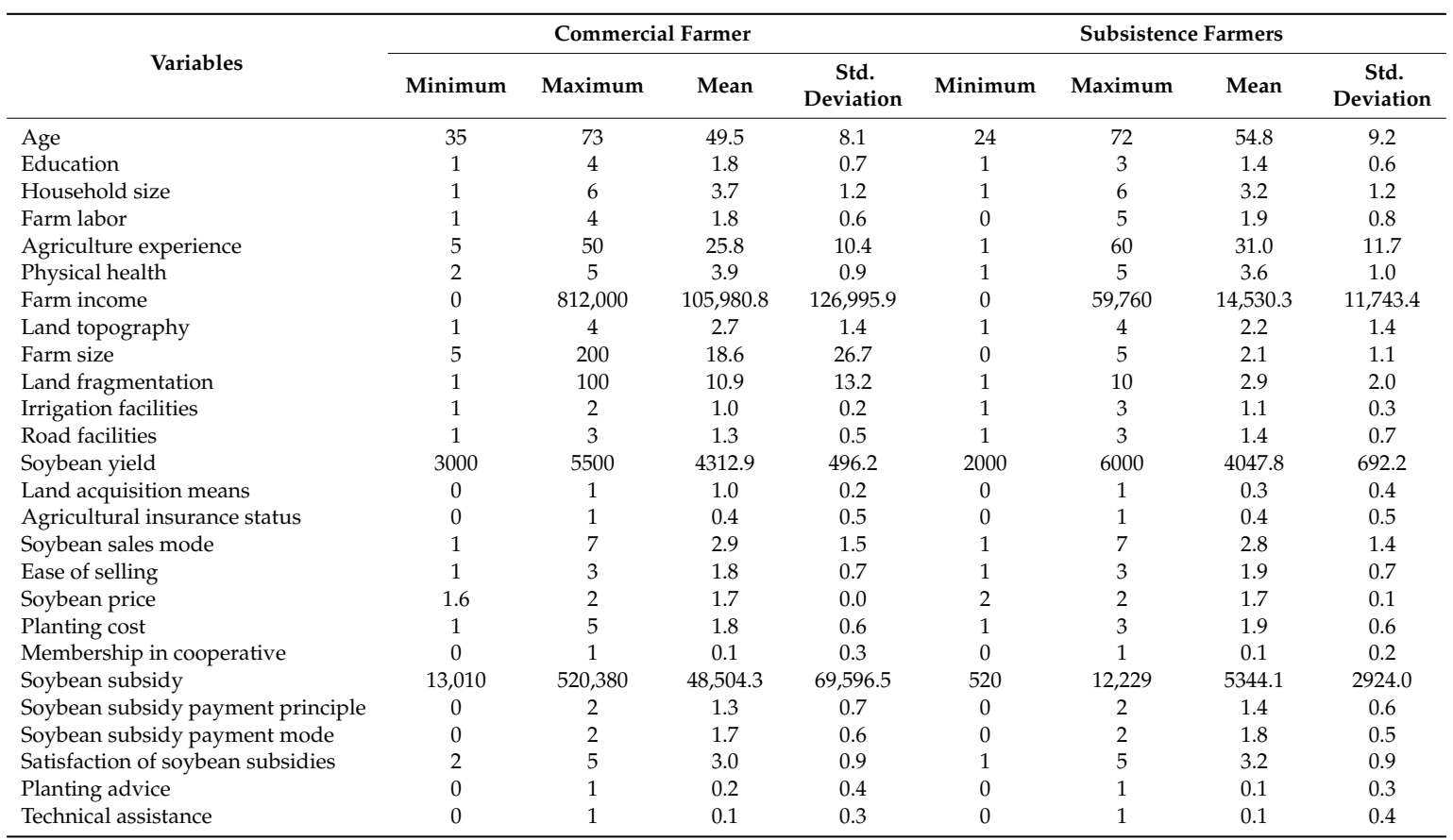

Farm income ( $1 \%$ level) is the most important factor to influence commercial farmers' planting behavior. This result is corroborated by Mandryk et al. [27] who reported that farmers' practical decisions were mostly driven by economic profit. Morgan [28] also mentioned that 'essentially farms are enterprises with economic objectives'. Income security is the primary consideration of current commercial farmers. After all, in 2015, the Ministry of Agriculture announced the elimination of the corn temporary reserve policy. The price of corn in Northeast China has decreased from $2.25 \mathrm{CNY} / \mathrm{kg}$ in 2014 to $1.42 \mathrm{CNY} / \mathrm{kg}$ in 2016. At the same time, the Ministry of Agriculture and Rural Affairs initiated the soybean producer subsidy in 2016. Planting soybean appears to be becoming more profitable. According to the survey results, farmers cultivated soybean was $1179.9 \mathrm{CNY}$ more than corn per hectare in 2017.

\subsubsection{Subsistence Farmers}

Subsistence farmers are those who grow food and other agricultural products primarily for personal consumption or to barter with others for products that are not grown or made on the farm [29]. Average farm size of the subsistence farmer is only 2.1 ha. As Table 2 shows, subsistence farmers' soybean planting behavior are significantly influenced by land topography ( $1 \%$ level). If the family's land geomorphology is complex, they will tend to grow soybean.

Agricultural insurance status (10\% level) is another factor affecting subsistence farmers' decision making. Agricultural production faces many risks, such as weather, disease, pest, price, etc., resulting in the instability of their income [30]. Agricultural insurance is a coping mechanism and an ex-ante adaptation measure purchased by agricultural producers and subsidized by the government to protect against potential risks and loss [31]. In the study area, if the farmer has bought soybean insurance, he or she will be willing to grow and increase soybean production because the insurance company will compensate them if the risk occurs.

Satisfaction of soybean subsidies ( $10 \%$ level) is also affecting subsistence farmers' planting behavior. Since 2017, the Chinese government finished the soybean target price subsidy policy and started 
soybean producer subsidy policy. The revenue of cultivated soybean surpassed corn. According to a report from Xu [32], in 2017, the revenue of planting soybean was 12.8CNY/acre higher than corn. As small-land holders, farmers are profit oriented; the more abundant the subsidies, the more willing they are to grow soybeans. This result is in accordance with Yu et al. [13] and Wu and Cai [14] who found that a subsidy has the effect of encouraging farms to increase crops. Although all the farmers did not know the soybean subsidy criteria in 2018, most of them are satisfied with the subsidy in 2017 and the average score is 3.2 .

\section{Conclusions and Policy Implications}

Soybean is an indispensable strategic crop to ensure national stability and food security. It is important for a country to ensure its long-term effective supply and balance in international trade. At present, China's soybean is in short supply. The Chinese government has made it the goal to ensure an ever-increasing supply of soybean. Based on a sample household survey conducted in 2018, this study has examined farmers' intentions to increased soybean cultivation after Chinese government issued soybean subsidy and rotation subsidy. The results indicated that $42.6 \%$ of the farmers would expand soybean planting area and $57.4 \%$ of the farmers would insist on the previous planting habits. The increase of soybean production is confronted with many constraints. This paper uses a binary logistic regression model to capture the factors underlying farmers' soybean increasing. The model is estimated across 155 families in the major soybean area of Heilongjiang Province. The results indicated that the farmer age, farm income, land topography, and ease of selling are the main drivers to influence farmers' behavior. This study also found that there a significant difference between commercial and subsistence farmers. In the case of commercial farmers, the farming experience and farm income appeared significantly more influential. In comparison, the subsistence farmers are more affected by land topography, agricultural insurance status, and satisfaction of soybean subsidies.

In completing this study, several policy implications are relevant. Since farm income is an important factor for farmers to expand soybean planting area, the government should make effort to increase farmers' income from soybean cultivation. First, Chinese soybean is a non-transgenic soybean. The yield of Chinese soybean is very low and almost $52 \%$ of the USA soybean. Project implementers should strengthen the research of molecular design and breeding, improve soybean yield, and promote the renewal of soybean breeding technology in China. Second, most of the soybean in China is mixed cultivate and mixed harvest. Price of soybean almost never accounts for quality and varieties. Whether a farmer's soybean product is organic or non-organic, high protein, or high oil content, they are all at the same price. Thus, the government needs to help farmers establish a classified planting system, storage by variety and quality, and help establish soybean price system according to soybean variety and quality. Through these policies, yield and price of soybeans will increase, and farmers will be more willing to grow soybeans if they earn more.

Large-scale planting is conducive to improving agricultural production efficiency. Manjunatha et al. [33] found that the land fragmentation has a reciprocal relationship with the farm efficiency. In view of the serious fragmentation of the local land, project implementers/decision makers should therefore promote the operation of moderate scale farms, reduce land fragmentation, and improve efficiency of soybean production. Another obstacle is the aging population of the rural labor force. Thus, the government needs to focus on training young farmers and subsidize them.

Insurance subsidy is a powerful tool for government to adjust farm structure. Yu et al. [13] studied the effects of the premium subsidies on crop acreage after the 2014 Farm Bill and found U.S. farmers expanded planting insured crops. However, insurance products in China are insufficient. Many farmers feel that the cost of insurance does not have much effect on mitigating risks. In 2018, the No 1 Central Document just proposed to pilot total cost insurance and income insurance for the three major grain crops of rice, wheat, and corn. Therefore, the government and insurance company should speed up the innovation of agricultural insurance product for soybean. 
Water is crucial to cultivation, and availability of irrigation not only affects the distribution of crops, but also affects crop yields. Greigc [34] revealed that the availability of water proved crucial to crop selection in Tanzania. Area irrigated (\% area equipped for irrigation) in the study area is very limited. One reported that if there is a well in his field, the soybean harvested will not reduce from the previous year. However, in some regions of Kedong, although farmers have wells, there is no electricity and they also cannot irrigate their land. Project implementers/decision makers should further implement medium- and large-sized irrigation, drainage and water conservation projects, and increase the irrigated areas.

Author Contributions: S.L., P.Z., and W.L. conceived and designed the experiments; S.L. and W.L. performed the experiment; S.L. analyzed the data and wrote the paper; B.M. revised this manuscript and give useful comments to improve this paper.

Funding: This study was funded by the National Natural Science Foundation of China (41601124); Fundamental Research Funds for Central Universities in the China (SWU019023); Excellent Young Foundation of Jilin Province (20190103141JH); 135 Planning and Featured Services Projects of IGA, Chinese Academy of Sciences (Y6H2091001 and IGA-135-04); The Key Deployment Projects of the Chinese Academy of Sciences(ZDBS-SSW-SQC, KFZD-SW-314).

Acknowledgments: We would like to thank the Urban Geography Research Team for field and data collection, and especially Pujia Yu for manuscript revisions.

Conflicts of Interest: The authors declare no conflict of interest.

\section{References}

1. Lee, G.A.; Crawford, G.W.; Liu, L.; Sasaki, Y.; Chen, X. Archaeological Soybean (Glycine max) in East Asia: Does Size Matter? PLoS ONE 2011, 6, e26720. [CrossRef] [PubMed]

2. Yang, S.G. Economics of Soybean Industry in China from Industry Perspective. Master's Thesis, China Agricultural University, Beijing, China, 2014.

3. Navarrete, M.; Le Bail, M. SALADPLAN: A model of the decision-making process in lettuce and endive cropping. Agron. Sustain. Dev. 2007, 27, 209-221. [CrossRef]

4. Saito, K.; Linquist, B.; Keobualapha, B.; Shiraiwa, T.; Horie, T. Farmers' knowledge of soils in relation to cropping practices: A case study of farmers in upland rice based slash-and-burn systems of northern Laos. Geoderma 2006, 136, 64-74. [CrossRef]

5. Seoa, S.N.; Mendelsohn, R. An analysis of crop choice: Adapting to climate change in South American farms. Ecol. Econ. 2008, 67, 109-116. [CrossRef]

6. Dury, J.; Garcia, F.; Reynaud, A.; Bergez, J. Cropping-plain decision-making on irrigated crop farms: A spatio-temporal analysis. Eur. J. Agron. 2013, 50, 1-10. [CrossRef]

7. Land Use, Soil Degradation, and Farmer Decision-Making: A Sondeo Report of Cavalier, Despa, Kols, and Saut Mathurine, Haiti. Available online: https://www.researchgate.net/publication/42764915 (accessed on 12 April 2018).

8. Asrat, S.; Yesuf, M.; Carlsson, F.; Wale, E. Farmers' preferences for crop variety traits: Lessons for on-farm conservation and technology adoption. Ecol. Econ. 2010, 69, 2394-2401. [CrossRef]

9. Katundu, M.A.; Mhina, M.L.; Mbeiyererwa, A.G.; Kumburu, N.P. Socio-Economic Factors Limiting Smallholder Groundnut Production in Tabora Region. Research Report 14/1, Dar es Salaam, REPOA. Available online: http://www.repoa.or.tz/documents/REPOA_RR_14.1.pdf (accessed on 15 May 2018).

10. Rahman, S. Determinants of crop choices by Bangladeshi farmers: A bivariate profit analysis. Asian J. Agric. Dev. 2008, 5, 29-41.

11. Caldas, M.M.; Bergtold, J.S.; Peterson, J.M.; Graves, R.W.; Earnhart, D.; Gong, S.; Lauer, B.; Brown, J.C. Factors affecting farmers' willingness to grow alternative biofuel feedstock's across Kansas. Biomass Bioenergy 2014, 66, 223-231. [CrossRef]

12. Popescu, A.; Alecu, I.N.; Dinu, T.A.; Stoian, E.; Condei, R.; Ciocan, H. Farm structure and land concentration in Romania and the European Union's agriculture. Agric. Agric. Sci. Procedia 2016, 10, 566-577. [CrossRef]

13. Yu, J.S.; Smith, A.; Sumner, D.A. The effects of the premium subsidies in the U.S. federal crop insurance program on crop acreage. Presented at the 2016 Annual Meeting, Boston, MA, USA, 31 July-2 August 2016. 
14. Wu, L.C.; Cai, H.H. Positive study on the effect of grain subsidy policy on farmers' planting behavior. Technol. Econ. 2010, 29, 68-73.

15. Paulrud, S.; Laitila, T. Farmers' attitudes about growing energy crops: A choice experiment approach. Biomass Bioenergy 2010, 34, 1770-1779. [CrossRef]

16. Narayanan, S.; Fallen, B. Evaluation of soybean plant introductions for traits that can improve emergence under varied soil moisture levels. Agronomy 2019, 9, 118. [CrossRef]

17. Zhang, P.; Sun, J.Y.; Li, L.J.; Wang, X.X.; Li, X.T.; Qu, J.H. Effect of soybean and maize rotation on soil microbial community structure. Agronomy 2019, 9, 42. [CrossRef]

18. Chu, Z.; Guo, J.P. Effects of climatic change on maize varieties distribution in the future of Northeast China. J. Appl. Meteorol. Sci. 2018, 29, 165-176.

19. Zhang, X.L.; Han, L. Which Factors Affect Farmers' Willingness for rural community remediation? A tale of three rural villages in China. Land Use Policy 2018, 74, 195-203. [CrossRef]

20. Menard, S. Applied logistic regression analysis. Technometrics 2012, 38, 192.

21. Xiao, R.; Liu, Y.; Huang, X.; Shi, R.X.; Yu, W.X.; Zhang, T. Exploring the driving forces of farmland loss under rapid urbanization using binary logistic regression and spatial regression: A case study of Shanghai and Hangzhou Bay. Ecol. Indic. 2018, 95, 455-467. [CrossRef]

22. Li, H.M.; Li, J.J. Analysis of the influencing factors of the planting behavior changes of southern farmers: A case study of the irrigation regions in Hunan Province. Res. Agric. Mod. 2015, 36, 617-623.

23. Mellor, J.W.; Malik, S.J. The impact of growth in small commercial farm productivity on rural poverty reduction. World Dev. 2017, 91, 1-10. [CrossRef]

24. Zhu, L.J.; Wang, Z.W. Analysis on technical efficiency and influencing factors of large-scale grain-production farmers in Heilongjiang Province. Resour. Sci. 2018, 40, 1583-1594.

25. Yang, S.; Guo, C.X.; Zhao, G.P.; Li, S.P. Productivity efficiency of cultivated land in different business entities of planting industry in Guanzhong region, China. J. Arid Land Resour. Environ. 2018, 32, 75-80.

26. Nahayo, A.; Omondi1, M.O.; Zhang, X.H.; Li, L.Q.; Pan, G.X.; Joseph, S. Factors influencing farmers' participation in crop intensification program in Rwanda. J. Integr. Agric. 2017, 16, 1406-1416. [CrossRef]

27. Mandryk, M.; Reidsma, P.; Kanellopoulos, A.; Groot, J.C.J.; Van Ittersum, M.K. The role of farmers' objectives in current farm practices and adaptation preferences: A case study in Flevoland, The Netherlands. Reg. Environ. Chang. 2014, 14, 1463-1468. [CrossRef]

28. Morgan, W.B. Agriculture in the Third World: A Spatial Analysis; International Affairs: London, UK, 1979; pp. 50-114.

29. Singh-Peterson, L.; Iranacolaivalu, M. Barriers to market for subsistence farmers in Fiji-A gendered perspective. J. Rural. Stud. 2018, 60, 11-20. [CrossRef]

30. Iturrioz, R. Agricultural Insurance. Available online: http://siteresources.worldbank.org/FINANCIALSECTOR/ Resources/Primer12_Agricultural_Insurance.pdf (accessed on 12 March 2015).

31. Farzaneh, M.; Allahyari, M.S.; Damalas, C.A.; Seidavi, A. Crop insurance as a risk management tool in agriculture: The case of silk farmers in northern Iran. Land Use Policy 2017, 64, 225-232. [CrossRef]

32. Xu, X.P. Farmer's Income Is Greatly Affected Since Corn and Soybean Subsidies “One Increase and One Decrease" in Northeast China. Available online: http://www.shuichan.cc/news_view-374145.html (accessed on 15 November 2018).

33. Manjunatha, A.V.; Anik, A.R.; Speelman, S.; Nuppenau, E.A. Impact of land fragmentation, farm size, landownership and crop diversity on profit and efficiency of irrigated farms in India. Land Use Policy 2013, 31, 397-405. [CrossRef]

34. Greig, L. An analysis of the key factors influencing farmer's choice of crop, kibamba ward, Tanzania. J. Agric. Econ. 2009, 60, 699-715. [CrossRef]

(C) 2019 by the authors. Licensee MDPI, Basel, Switzerland. This article is an open access article distributed under the terms and conditions of the Creative Commons Attribution (CC BY) license (http://creativecommons.org/licenses/by/4.0/). 